\title{
The role of the West Spitsbergen Current in the formation of ice edge position
}

\author{
ALEXANDER MAKSHTAS and IGOR PODGORNY
}

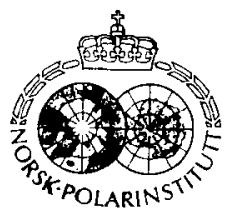

Makshtas. A. P. \& Podgorny, I. A. 1991: The role of the West Spitsbergen Current in the formation of ice edge position. Polar Research 9(2), 207-210.

The intensity of sea-ice interaction in the Fram Strait is estimated from hydrographic data by use of three different methods. Preliminary results concerning fresh water formation rate are reported.

A. P. Makshtas and 1. A. Podgorny, Arctic and Antarctic Research Institute, 38 Bering St., 199226 St. Petersburg, U.S.S.R.

It is commonly accepted that advective heat fluxes in the atmosphere and the hydrosphere along with sea ice transport from the Arctic Ocean control in general the spatial ice distribution in the Greenland Sea. The advection of warm Atlantic Water appears to be the main factor in the formation of the ice edge position and the upper layer of low salinity water in the northcast part of the Fram Strait, where the West Spitsbergen Current (WSC) interacts very actively with the jce edge.

The intensity of this interaction has been investigated by many oceanographers. for example Quadfasel et al. (1987) who used temperature and salinity profiles from two oceanographical stations in the WSC (one at $77^{\circ} 30^{\prime} \mathrm{N}$ and one at $80^{\circ} 20^{\prime} \mathrm{N}$ ). They estimated the influence of Atlantic Water on

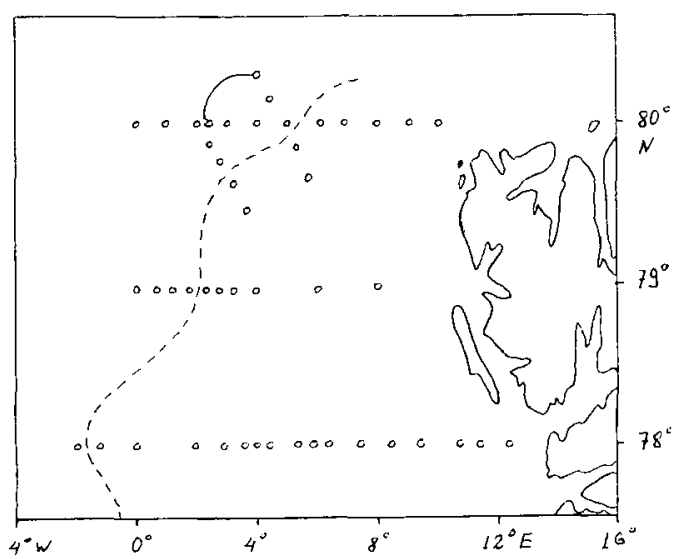

Fig. 1. Location of all hydrographic stations used in the horizontal maps. The solid line indicates the ice-breaker drift during operation of the two-day ice station. The dotted line indicates the ice margin position (May 1989). the ice edge formation and found the difference in the heat content in the upper $100 \mathrm{~m}$ layer between the two profiles to be $5.03 \times 10^{8} \mathrm{~J} / \mathrm{m}^{2}$ with an associated salt deficit of $3 \mathrm{~g} / \mathrm{cm}^{2}$. This might have been caused by the daily retreat of the ice edge of about $5 \mathrm{~km}$ with a thickness of $1.5 \mathrm{~m}$.

More recently Untersteiner (1988) described the above processes on the basis of a steady heat-balance model in which the ice edge was interpreted as a wedge with a thickness changing from zero on the ice margin $102.5 \mathrm{~m}$ at $150 \mathrm{~km}$ to the north The relevant heat flux from the upper ocean layer to melting ice was estimated as being about to $300 \mathrm{~W} / \mathrm{m}^{2}$. Neverthcless, the data of Vinje \& Finnekåsa (1986) indicate considerablc ice floe thicknesses immediately near the ice edge as being up to $2 \mathrm{~m}$.

On the basis of these data and our own observations in the area under study, we suggested the wedge description to be rather questionable, and we have therefore tried to estimatc the role of the WSC in the ice edge and upper layer formation anew, paying particular attention to the localization of the intensive ice melting. For this purpose, during the $\mathrm{R} / \mathrm{V}$ OrTO SCHMIDT cruise in May 1989 two oceanographical sections up and down the western branch of the WSC were defined and a two-day ice station was established for collecting data. The study area and the station locations are shown in Fig. 1.

Horizontal distributions of the main oceanographical characteristics in the upper $100 \mathrm{~m}$ in the castern part of the Fram Strait are shown in Fig. 2. One can see that $T$ and $S$ fields vary significantly from place to place. especially under the sea ice. The distribution of the heat content $(Q)$ in layers $0-30 \mathrm{~m}$ and $30-100 \mathrm{~m}$ is similar to that of $T$ and $S$ near the surface. The main decrease of $\mathrm{Q}$ takes place in the vicinity of the compact ice margin between $80^{\circ} 16^{\prime} \mathrm{N}$ and $80^{\circ} 03^{\prime} \mathrm{N}$. This may be illustrated with the aid of Table 1, where "normalized" differences in $Q(\Delta Q)$ between several profiles of the first section (Fig. $2 A)$ are determined. The origin of the horizontal coordinatc $x$ corresponds to $80^{\circ} 16^{\prime} \mathrm{N}$. Temperature and salinity profiles from two stations in the WSC (one at $80^{\circ} 16^{\prime} \mathrm{N}$ and one at $80^{\circ} 03^{\prime} \mathrm{N}$ ) are plotted in Fig. 3. 
208 Alexander Makshtas \& lgor Podgorny
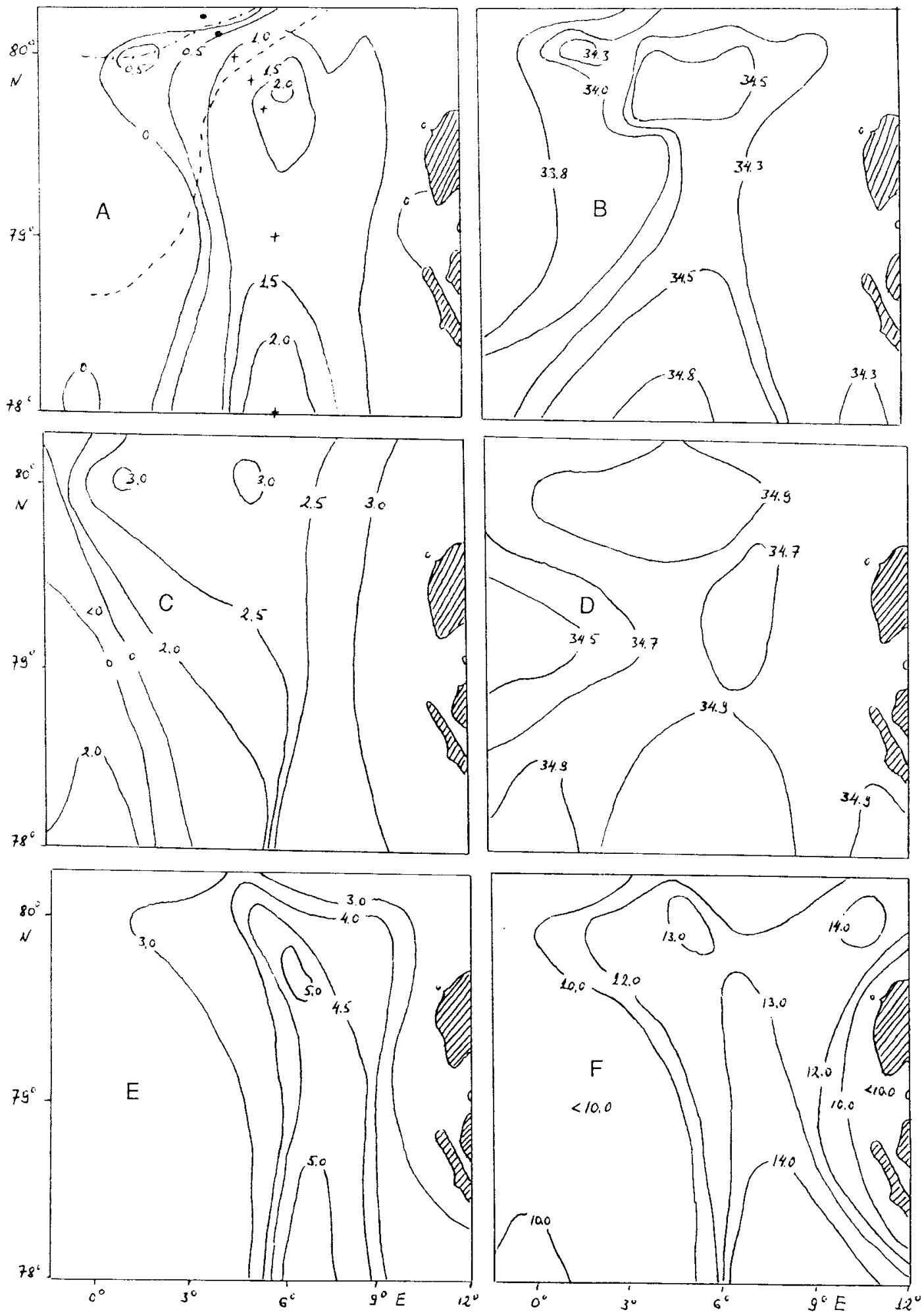
Table 1. "Normalized" differences $\Delta \mathrm{Q}\left(\mathrm{J} / \mathrm{m}^{+}\right)$at the section along the WSC (see Fig. 2).

\begin{tabular}{cccccc}
\hline$\Delta \mathrm{z} / \Delta \mathrm{x}$ & $0-15.6$ & $15.6-53.5$ & $53.5-72.1$ & $72.1-153.5$ & $153.5-264.7$ \\
\hline $0-30$ & -370 & -65 & 25 & -16 & 18 \\
$30-50$ & -272 & 22 & -15 & 40 & -2 \\
$50-100$ & -9 & 53 & -102 & -12 & -10 \\
$100-200$ & -57 & - & -37 & 7 \\
\hline
\end{tabular}

Note: $\Delta Q$ is the average heat content change of a cubic metre seawater per one metre distance. $\Delta z(m)$ characterizes the upper and lower boundaries of a layer and $\Delta x(\mathrm{~km})$ is the distance between two successful stations.
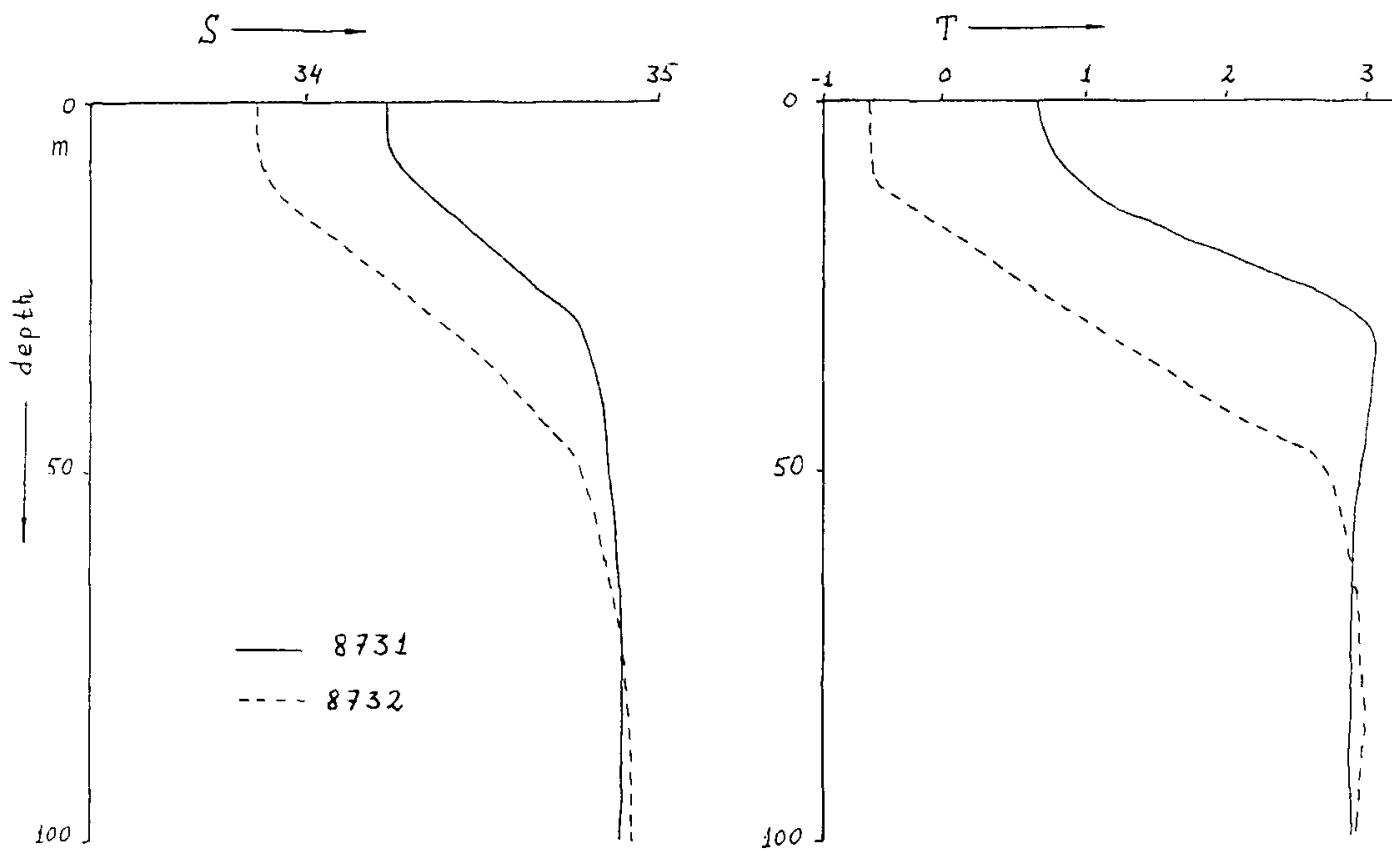

Fig. 3. Vertical profiles of temperature $\left({ }^{\circ} \mathrm{C}\right)$ and salinity $(\% O)$ at stations $8732\left(80^{\circ} 16^{\prime} \mathrm{N}, 4^{\circ} 05^{\prime} \mathrm{E}\right)$ and $8731\left(80^{\circ} 03^{\prime} \mathrm{N}, 4^{\circ} 30^{\prime} \mathrm{E}\right)$.

The most intensive interaction between the WSC and sea ice appears to be in the upper $50 \mathrm{~m}$ layer, where $\Delta Q$ has its maximum change. We suggest that variations of $\Delta \mathrm{Q}$ in the 50 $200 \mathrm{~m}$ layer arc mainly linked to the uncertainty in determining $Q$, and, perhaps, to eddy structures (Johannessen et al. 1987). It should be mentioned also that the heat transfer from the open ocean to the atmosphere which was determined from the ship's meteorological data using the algorithm proposed by Makshtas et al. (1989) was quite close to zero $\left(\cong 40 \mathrm{~W} / \mathrm{m}^{2}\right)$ during the pcriod of observations and has not been taken into consideration.

Fig. 2. Horizontal distributions of main oceanographical characteristics in the upper $100 \mathrm{~m}$ layer in the east area of the Fram Strait (May 1989): A, B-surface temperature $\left({ }^{\circ} \mathrm{C}\right.$ ) and salinity (\%); C, D - the same at $100 \mathrm{~m} ; \mathrm{E}, \mathrm{F}$ - heat content $\left(\mathrm{J} / \mathrm{m}^{2} \times\right.$ $\left.10^{8}\right)$ in layers $0-30$ and $30-100 \mathrm{~m}$; ice concentrations: $0.1-0.2$ $(--), 0.9-1.0(-\cdot-) ;(+)$ - station locations used in Table 1; (•) - stations 8731 and 8732 .
Let us examine the heat balance equation to evaluate the heat flux from the upper ocean layer upwards near the margin of sea ice:

$\rho_{w} C_{w} \frac{\partial T}{\partial t}=-\operatorname{div} F$

where $\rho_{w}$ and $C_{w}$ are the density and the specific heat of seawater and $F$ is the heat flux in the WSC.

Because of the weak temporal variability of the seawater temperature $T$ near the ice margin, (1) may be rewritten as:

$\rho_{w} C_{w} \overline{\mathbf{u}}_{w} \frac{\partial T}{\partial x}=-\left(\frac{\partial \mathbf{F}_{x}}{\partial x}+\frac{\partial \mathbf{F}_{z}}{\partial z}\right)$

where $\overline{\mathbf{u}}_{w}$ denotes the northward average current velocity.

We found the term $\partial \mathrm{F}_{\mathrm{x}} / \partial \mathrm{x}$ due to turbulence to be small in comparison with the term $\partial F_{2} / \partial z$ and integrated (2) through the layer of the most intensive ice-sea interaction with the depth $h$ :

$\overline{\mathrm{u}}_{\mathrm{w}} \frac{\partial}{\partial \mathrm{x}} \int_{\mathrm{o}}^{\mathrm{h}} \rho_{\mathrm{w}} \mathrm{c}_{\mathrm{w}} \mathrm{Tdz}=\mathrm{F}_{\mathrm{o}}-\mathrm{F}_{\mathrm{h}}$. 
So. using (3). taking $\overline{\mathrm{u}}_{\mathrm{u}}=0.1 \mathrm{~m} / \mathrm{s}$ (Aagaard et al. 1985) and $\mathrm{h}=50 \mathrm{~m}$, and considering a heat flux through the stable pycnocline as very weak, we can estimate $F_{n}$ as $1600 \mathrm{~W} / \mathrm{m}^{2}$ on the basis of Table 1.

This heat flux is suggested to be generally localized between $80^{\circ} 03^{\prime}$ and $80^{\circ} 16^{\prime} \mathrm{N}$. where ice concentration changed from 0.5 to 1.0. Direct measurements to the north of this region, where the two-day ice station was located (Fig. 1). gave an experimental estimate of the ice bottom melting rate of about $2.5 \mathrm{~cm} /$ day, corresponding to $F_{\text {, }}$ being only up to $90 \mathrm{~W} / \mathrm{m}^{2}$.

To prove our result we also used another approach, having examined the salt balance equation:

$\int_{i}^{h} \rho_{u} \frac{d S_{u}}{d t}=\left(S_{u}-S_{i}\right) \rho_{i} \frac{d h}{d t}$.

where $S_{k}$ and $S$, are the seawater and the sea ice salinities, and $\rho_{1}$ and $h_{i}$ the density and the spatially averaged thickness of sea ice. The method, bcing similar to that used by Quadfasel $\mathrm{ct}$ al. (1987). has been used again with $S_{1}=2 \%, h=50 \mathrm{~m}$ and salinity profiles. as plotted in Fig. 3. We found the value of $\mathrm{dh}_{2} / \mathrm{dt}$ to he of $0.3 \mathrm{~m} /$ day and the associated heat flux of $700 \mathrm{~W} / \mathrm{m}^{2}$ as not being remarkably different from the above estimatc. It should be mentioned that our cstimate of $\mathrm{dh}_{\mathrm{\gamma}}$ 'dt does not differ very much from that reported by Josberger (1987), who carried out direct measurements of the ice melting rate in the marginal ice zonc and found it to be up to $0.5 \mathrm{~m} / \mathrm{day}$.

Our results suggest that the greater part of fresh water and heat fluxes in the northeastern area of the Fram Strait were formed under the narrow ice belt with width $\Delta x=15 \mathrm{~km}$ running zonally along the compact ice margin. However, there is some uncertainty regarding this conclusion. It is possible that the oceanographical characteristics of the analysed stations simply corresponded to the different water masses of the West Spitsbergen and the East Greenland Currents.

To examine the above results once again let us use the ice mass balance equation:

$\mathrm{h}_{\mathrm{i}} \overline{\mathrm{u}}_{\mathrm{j}}=\frac{\mathrm{dh}}{\mathrm{dt}} \Delta \mathrm{x}$.

Here $\bar{u}_{i}$ denotes the $x$-component of the drift. If the advection of warm Atlantic Water from the south, determining the value of $\mathrm{dh}_{3} / \mathrm{dt}$, and the advection of sea ice from the north kecp ice edge stationary. (5) is true. Assuming $h_{1}=2 \mathrm{~m} . \Delta x=15 \mathrm{~km}$. we get $\bar{u}_{i}=5.6 \mathrm{~cm} / \mathrm{s}$ and $3.5 \mathrm{~cm} / \mathrm{s}$ corresponding to $F_{u}=$ $1600 \mathrm{~W} / \mathrm{m}^{2}$ and $700 \mathrm{~W} / \mathrm{m}^{2}$ respectively. These estimates of $\vec{u}$ do not differ very much from the value $\overline{\mathrm{u}}_{\mathrm{i}}=6.5 \mathrm{~cm} / \mathrm{s}$ reported by Vinje \& Finnekắsa (1986).

Taking the northward transport in the WSC at $79^{\circ} \mathrm{N}$ in the upper $50 \mathrm{~m}$ layer as equal to $0.5 \mathrm{~Sv}$ (Hanzlick 1983). and assuming that three quarters of this current continues to flow to the north and the remaining gocs round Spitsbergen, we found from (4) that the fresh water formation rate in the region of our observation is $120 \mathrm{~km}^{3} /$ year. Moreover, some fresh water appears to be formed to the north, but according 10 our data it is not possible to estimate the complete amount. According to Quadfasel et al (1987) and Untersteiner (1988), an unknown part of this water is thought to recirculate and join the East Greenland Current.

Recently we investigated the interaction between the castern branch of the WSC and the sea ice to the north of Spitsbergen. Direct measurements, carried out during the $\mathrm{R} / \mathrm{V}$ OTTO SCHMIDT cruise in April 1991 to the east of the ice margin in this region. gave an estimated ice melting rate of about $9 \mathrm{~cm} /$ day. The maximum melting rate was not over the warmest Atlantic Water, but rather over the continental slope, being more than that reported above. We suggest this fact to be possibly connected with the recent results by Padman \& Dillon (1991) who investigated water mass modification near the Yermak plateau and found it to be linked to current-topography interactions.

A detailed discussion of such a mechanism is beyond the scope of this study and will be presented in our next paper. We would like to mention, however. that the region north of Spitsbergen probably corresponds better with Untersteinder's (1988) "ice wedge" description than with the northeastern area of the Fram Strait. In our opinion. the latter may be associated with the existence of a mechanism that appears to neutralize the suppression of the heat flux from the ocean upwards despite the rapid ice melting and when a strong vertical mixing by surface waves (evidently the main mechanism of vertical heat transfer in the northeastern part of the Fram Strait) is absent.

As is well-known the storage of fresh water in the Arctic Ocean represents one of the major uncertainties in understanding both Arctic and global climate (Aagaard \& Carmack 1989). Thus, the importance of the problem demands further observational and modelling efforts to improve our knowledge of air-ice-sea interactions in the Fram Strait.

Acknowledgements. - We would like to acknowledge two anonymous reviewers for their valuable comments on an early draft of this paper. We are also grateful for the help provided by the officers and research scientists aboard the ice-breaker R V OTTO SCHMIDT

\section{References}

Aagaard. K. A.. Darnall, C., Foldvik, A., \& Tørresen. T. 1985: Fram Strait Current measurements. 1984-1985, Joint data report. Bergen. Norway. $85 \mathrm{pp}$.

Aagaard. K. A. \& Carmack, E. C. 1989: The role of sea ice and other fresh water in the Arctic circulation. J. Geophys. Res. 94 (ClO). 14485-14498.

Hanzlick, D. J. 1983: The West Spitsbergen Current: transport, forcing and variability, Ph.D. thesis, University of Washington. Seattle.

Johannessen, J. A.. Johannessen, O. M., Svendsen. E., Shuchman. R., Manley, T., Camphell, W. J., Josherger, E. G., Sandven. S. Gascard, J.-C., Olaussen, T., Davidson, K. \& Van Leer. J. 1987: Mesoscale eddies in the Fram Strait marginal ice zone during the 1983 and 1984 Marginal Ice Zone Expcriment. J. Geophys. Res 92 (C7), 6754-6772.

Josberger. E. G. 1987: Bottom ablation and heat transfer coefficients from the 1983 marginal ice zonc experiments. $J$. Geophys. Res. 92 (C7), 7012-7016.

Makshtas, A. P.. Tikmachev, V. F. \& Ivanov, B. V. 1989: Energy exchange between the atmosphere and the underlying surface in the marginal ice zone. Workshop proceedings 'Regional and Mezoscale modelling of Ice Cover Oceans'. NRSC Conference Report N 3, 186-190.

Padman, L. \& Dillon. T. M. 1991: Turbulent mixing near the Yermak plateau during the Coordinated Eastern Arctic Expcriment. J. Geophys. Res. 96(C) 3). 4769-4782.

Quadfasel. D. J., Gascard, J -C. \& Koltermann, K.-P. 1987: Large-scale oceanography in Fram Strait during the 1984 Marginal Ice Zone Experiment. J. Geophys. Res. 92 (C7), 6719-6728.

Untersteiner, N. 1988: On the ice and heat balance in Fram Strait. J. Geophys. Res. 93 (C1), 527-533.

Vinje, T. \& Finnekåsa, O. 1986: The ice transport through the Fram Strait. Norsk Polarinst. Skrifter $186.39 \mathrm{pp.}$ 